\title{
Use of natural and anthropogenic resources by Olrog's Gull Larus atlanticus: implications for the conservation of the species in non-breeding habitats
}

\author{
MARÍA PAULA BERÓN, MARCO FAVERO and AGUSTINA GÓMEZ LAICH
}

\section{Summary}

We studied the exploitation of crab-beds and fishing grounds by Olrog's Gulls Larus atlanticus in non-breeding areas along the coast of Buenos Aires province, Argentina. During 2004 and 2005, censuses were performed in different areas of Mar Chiquita coastal lagoon and Mar del Plata harbour. Additionally, from April to August 2005 the movements of five non-breeding individuals were studied by means of radio-telemetry. At both study sites the highest numbers of Olrog's Gulls were observed between June and August. A total of 278 radio-tracked locations (from 407 samples) were registered. All the tracked individuals showed strong site fidelity, with $96 \%$ of the radio signals registered in the vicinity of the lagoon's mouth, associated with both crab-beds and areas where sport-fishing activities took place. Conservation issues in nonbreeding areas should be tackled in the near future, given the conservation status of this species (Vulnerable) and the fact that each year several Olrog's Gulls are being killed because of their interaction with sport-fishing activities.

\section{Resumen}

Se estudió la utilización de cangrejales y áreas de pesca por la Gaviota de Olrog durante el periodo no reproductivo. Durante los años 2004 y 2005 se realizaron censos en diferentes áreas de la Laguna Costera Mar Chiquita y el Puerto Mar del Plata, Provincia de Buenos Aires, Argentina. En ambos sitios de estudio el mayor número de individuos se observó entre los meses de junio y agosto. Adicionalmente entre los meses de abril y agosto de 2005 se estudiaron los movimientos de cinco individuos no reproductores mediante el uso de radio-transmisores. De un total de 407 muestras se obtuvieron 278 localizaciones. Todos los individuos instrumentados mostraron una alta fidelidad al sitio. El $96 \%$ de las localizaciones se registraron en cercanías de la desembocadura de la laguna, asociadas a cangrejales y areas de pesca deportiva. Considerando el estatus de conservación de la Gaviota de Olrog ('Vulnerable') y los efectos negativos de su interacción con la pesca deportiva, programas de conservación en áreas no reproductivas deben ser implementados.

\section{Introduction}

Olrog's Gull Larus atlanticus is an endemic species of the Atlantic coasts of southern South America and the only gull considered Vulnerable in the IUCN Red List (BirdLife International 2004). This species has an estimated population of 2,300 breeding pairs (Yorio et al. 1999) and reproduces in just 10 colonies situated in two areas along the Patagonian coast between $39^{\circ} 12^{\prime} \mathrm{S}$ 
and $45^{\circ} 11^{\prime} S$ (Delheyet al. 2001, Yorio et al. 2005).

Previous studies on the diet of the Olrog's Gull in non-breeding sites have shown that grapsid crabs (Chasmagnathus granulatus and Cyrtograpsus angulatus) are its main prey, with fish, snails, insects, barnacles and other crab species being taken with lower frequency (Spivak and Sánchez 1992, Copello and Favero 2001, Delhey et al. 2001, Berón 2003). In non-breeding areas along the coast of Buenos Aires Province (Argentina), Olrog's Gulls have also been observed associated with fishing activities. In this area, Olrog's Gulls associate with sport fishermen fishing from the coast or small boats, and with fishing activities at commercial harbours. At Mar del Plata harbour, Olrog's Gulls have been observed feeding on waste discarded from boats around the uploading area and on discarded fish from nearby factories (Martinez et al. 2000).

Commercial harbours and other fishing-related activities can provide additional sources of food for seabirds (Giaccardi and Yorio 2004). The association of seabirds with fishing activities can have effects on a particular species by modifying its foraging behaviour or by increasing survival rates of all or particular age classes (Yorio et al. 2005). Fishing activities also pose a threat to seabirds due to the incidental mortality associated with them. Many seabirds die each year due to consumption of fishing-related items (e.g. hooks and fishing lines), entanglement in fishing nets and collisions with fishing gear (Croxall 1998, Tasker et al. 2000, Favero et al. 2003).

Although several studies have shown the existence of an association between Olrog's Gull and fishing activities (Martinez et al. 2000, Copello and Favero 2001), no studies about the differential utilization of these resources by different age groups have been undertaken. Neither is it known whether the individuals that feed in natural habitats additionally use urban areas where there are commercial or sport-fishing activities. The objective of this study was to determine the differential use of natural and anthropogenic areas by individuals of different age classes of Olrog's Gull.

\section{Methods}

This study was conducted from May to October of 2004 and 2005 at Mar Chiquita coastal lagoon $\left(37^{\circ} 46^{\prime} \mathrm{S}, 57^{\circ} 27^{\prime} \mathrm{W}\right)$ and Mar del Plata harbour $\left(38^{\circ} 03^{\prime} \mathrm{S}, 57^{\circ} 32^{\prime} \mathrm{W}\right)$, Buenos Aires, Argentina. Both sites are widely used by Olrog's Gulls as wintering areas during these months (Figure 1 ). Three age classes of Olrog's Gull were distinguished based on plumage characteristics: juveniles (1- to 2-year-old birds), subadults (3-year-old birds) and adults (older than 4 years old and potential breeders) (see Harrison 1983). One or more point censuses of 1 hour were conducted monthly at each study sites $(n=65$ and $n=12$ in Mar Chiquita and Mar del Plata harbour, respectively) (Bibby et al. 1997). The mean monthly abundance of each age class was estimated for both study areas (years 2004 and 2005 combined). For three different locations at Mar Chiquita coastal lagoon, a percentage of the number of observations of the individuals of each age class was calculated (years 2004 and 2005 combined).

With the aim of analysing the use of foraging patches in non-breeding areas, in April 2005 four juveniles and one subadult were captured at Mar Chiquita coastal lagoon using bal-chatri traps (Blom 1987). Each individual was fitted with a VHF radio-transmitter (Advanced Telemetry Systems, effective range at sea level estimated at $4 \mathrm{~km}$ ) attached to the two central back feathers using waterproof tape. The average mass of the instruments was $11.0 \mathrm{~g}$, which represented approximately $1.4 \%$ of the individual's body mass (mean $=784 \mathrm{~g}, \mathrm{SD} \pm 165.20, n$ $=5$ ). Individuals were located at intervals that ranged from 30 minutes to 2 hours using a singlechannel receiver (Rı6ıA model, Advanced Telemetry Systems) connected to a null peak directional. Radio signals were regularly monitored from tracking stations between the north end of Mar Chiquita coastal lagoon and Mar del Plata harbour. The location of each gull was estimated by triangulation from the direction of the signals obtained from two receiver stations or by identifying the individual with one receiver if it was close enough to the observer. The latter was possible since each of the radio-tracked individuals carried a unique combination of metal and plastic bands. The study area was divided according to the characteristics of the 


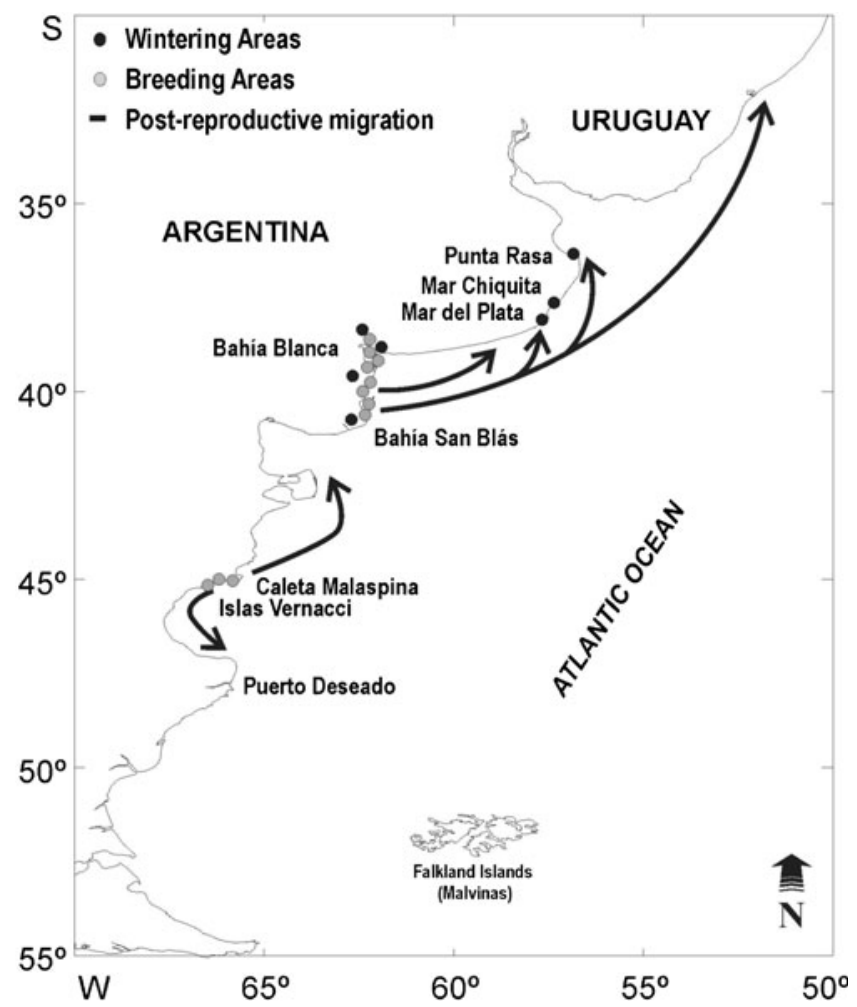

Figure 1. Location of Olrog's Gull breeding and wintering areas and its movements during the non-breeding season.

foraging patches into: crab-bed patches (A, B, and C), crab-bed patch with sport-fishing (D), sandy beach with sport-fishing (E) and rocky shore with sport-fishing (F) (see Figure 3).

Two contingency table analyses were made, one comparing the use of each of the foraging patches (A, B, C, D, E and F) by the radio-tracked individuals $(1,2,3,4$ and 5$)$ and the other comparing the age class composition of three foraging patches $(\mathrm{C}, \mathrm{D}$ and $\mathrm{E})$.

\section{Results}

From May to October 2004, juveniles were the most frequently observed individuals in Mar Chiquita coastal lagoon (52\%), whereas in Mar del Plata harbour adults were most abundant (50\%). In Mar del Plata harbour adults were observed until September whereas in Mar Chiquita they remained until November. During 2005, juveniles were also dominant in Mar Chiquita $(53 \%)$ while in the harbour no dominance of any age class was observed (juveniles $=36 \%$, subadults $=31 \%$, adults $=33 \%$ ).

In Mar Chiquita juveniles, abundance remained constant through the non-breeding stage, while adult and subadult groups showed a peak of abundance in June, July and August. In Mar del Plata harbour, all age classes reached the highest numbers in July (years 2004 and 2005 combined) (Figure 2).

A total of 278 radio-tracked locations (from 407 samples) were registered between April and August 2005. In the remaining 129 samples in which no signal was detected, individuals were assumed to be out of range. All the individuals showed strong site fidelity, with $96 \%$ of the 278 radio-tracked locations registered in the vicinity of the lagoon mouth, associated with patches 

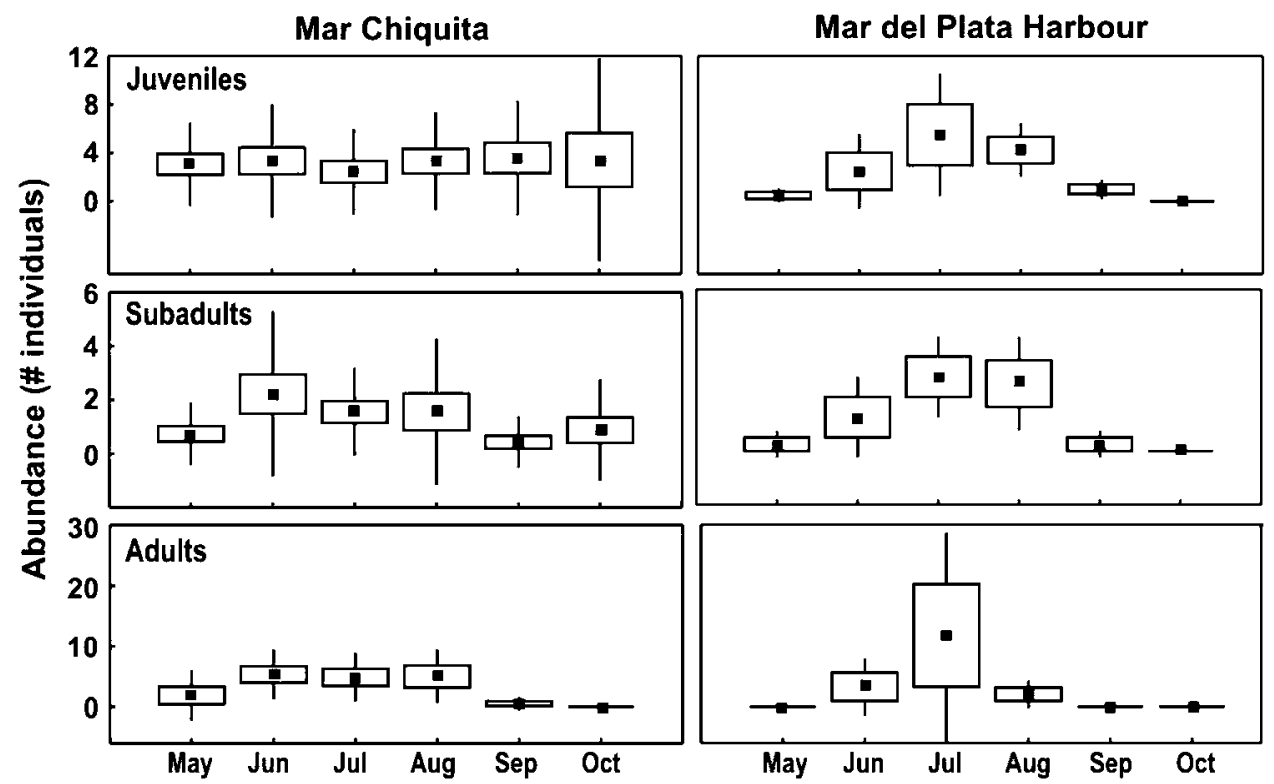

Figure 2. Abundance of juvenile, subadult and adult Olrog's Gulls at Mar Chiquita coastal lagoon and Mar del Plata harbour. Dots show mean values, boxes the standard error and whiskers the standard deviation.
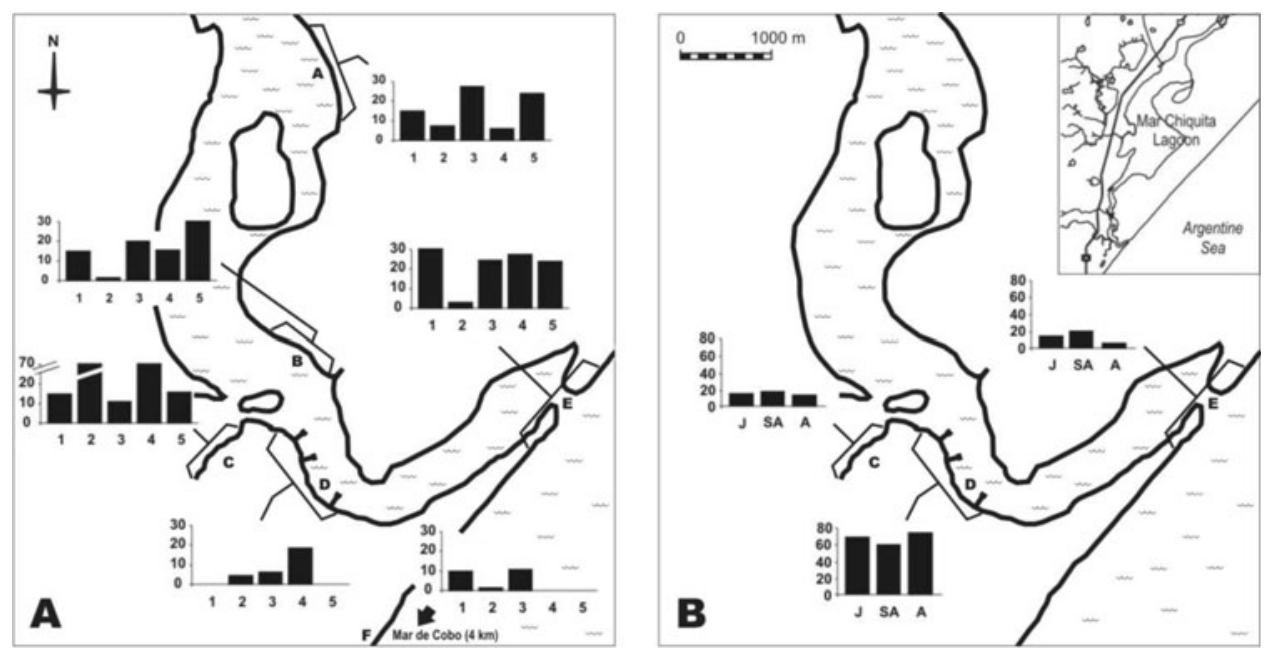

Figure 3. Percentage of signals of each radio-tracked Olrog's Gull (individuals 1, 2, 3, 4 and 5) at six different foraging patches $(A)$, and the percentage of individuals of each age class (A, adults; SA, subadults; J, juveniles) observed during the censuses performed at three different areas of Mar Chiquita coastal lagoon (B).

with crab-beds and/or the occurrence of sport-fishing activities. A small number of signals emanated from a rocky shore at Mar de Cobo $\left(37^{\circ} 58^{\prime} \mathrm{S}, 57^{\circ} 34^{\prime} \mathrm{W}\right)$, a small village situated $4 \mathrm{~km}$ south of Mar Chiquita coastal lagoon (Figure $3 \mathrm{~A}$ ). Despite the lack of signals in Mar del Plata during the sampling it should be considered as a possibility that the $32 \%$ of 'no signals' in Mar 
Chiquita could correspond to days when juveniles were foraging in the commercial harbour. While some individuals were principally associated with sport-fishing activities (e.g. individual 1) or with crab-bed areas (e.g. individuals 2 and 5), others were mainly recorded in areas where both crab-beds and fishermen were found (e.g. individuals 3 and 4). Significant differences between tracked individuals were observed in the use of area $\mathrm{B}\left(\chi^{2}{ }_{4}=33.8, P<\right.$ 0.001), $\mathrm{C}\left(\chi_{4}^{2}=110.2, P<0.001\right)$ and $\mathrm{D}\left(\chi_{4}^{2}=34.8, P<0.001\right)$. Some of these gulls (particularly individual 2) showed a marked fidelity to the use of particular patches. Censuses showed a similar use of patches by juveniles, subadults and adults, with particular preference for the use of patch $\mathrm{D}$ where both crab-beds and sport-fishing occurred $\left(\chi_{4}^{2}=356.6, P<\right.$ o.0oo1 $)$ (Figure $3 \mathrm{~B}$ ).

\section{Discussion}

During the study, the highest numbers of Olrog's Gulls were observed between June and August irrespective of the age class considered. However, the increase in abundance was steeper in the case of adults at Mar del Plata commercial harbour. The decrease in the number of adults by September could be linked with the spring migration of breeders to reproductive areas south of the study site. This is in line with the phenology of the species reported for colonies located in the northern tip of San Jorge's Gulf (Chubut, Argentina), where nest-building and egg-laying begin by late October (Yorio et al. 2005). Subadults and juveniles were observed throughout the study period. Additional observations show that both study sites constitute important foraging sites for non-breeders throughout the year.

Radio-telemetry data for non-breeding birds revealed a restricted pattern of movement and a strong fidelity to certain foraging patches, especially to crab-bed patches and beaches where sport-fishing activities usually took place. Individuals occasionally moved up to $4 \mathrm{~km}$ south to a village were they might also take advantage of rocky intertidal pools available along the shore. The absence of radio-telemetry information for adults does not allow the comparison of the foraging range of the different age classes. Future studies to determine the movements of adult birds will permit this comparison.

Olrog's Gulls have frequently been observed associated with commercial fishing activities at Mar del Plata harbour (Martinez et al. 200o). Similarly, in Mar Chiquita coastal lagoon, juveniles of this species have often been observed making use of sport-fishing by-products (Copello and Favero 2001, Berón 2003). Fishermen daily discard bait, offal from fish processing, broken fishing lines and nylon bags, throwing them into the water or leaving them on jetties and on the beach, places frequently used by the gulls to rest and feed. Olrog's Gull and other species (e.g. Larus dominicanus) can be injured by the ingestion of discarded baited hooks, fish guts and heads containing hooks inside them, or even become entangled with fishing lines and nylon bags. For example, during 2004 and 2005 several Olrog's Gulls were found dead or seriously injured after the ingestion of fishing discards, some of them containing hooks (Silva et al. 2005, Berón, unpubl. data). Common Oystercatchers (Haematopus palliatus) are also affected by human activities at Mar Chiquita coastal lagoon, with human disturbance an important factor in the low reproductive success of this species due to the destruction of nests and killing of chicks (Favero et al. 2001). Since sportfishing is a very important activity all along the shores used by the Olrog's Gull as winter quarters, mortalities can have important effects on this species given the small size of its populations.

A substantial change in the conservation strategy for this threatened species is needed, to ensure that management programmes consider conservation issues affecting individuals in nonbreeding areas. The strong site fidelity to Mar Chiquita coastal lagoon observed in the tracked individuals shows the importance of this area for the species. The information presented in this study could contribute to the establishment of restricted or managed areas along the lagoon in order to minimize the negative effects of human activities on birds. Moreover, the bird banding that is currently taking place during each non-breeding period at Mar Chiquita coastal lagoon will contribute to our understanding of migration patterns in this species. 


\section{Acknowledgements}

This study was supported by Fundación Antorchas (Grant 13900) and Universidad Nacional de Mar del Plata (Grant 15/E238). We thank Dr Pablo Yorio (Wildlife Conservation Society CENPAT) for providing the radio-telemetry antennas and receivers. We are grateful to A. Gatto, R. Mariano-Jelicich, G. García, M. Ghys, L. Josens, J. Pedrana and L. Mauco for their assistance in the field.

\section{References}

Berón, M. P. (2003) Dieta de juveniles de Gaviota Cangrejera (Larus altanticus) en estuarios de la Provincia de Buenos Aires. El Hornero 18: 113-117.

Bibby, C. J., Burgess, N. D. and Hill, D. A. (1997) Bird census techniques. London: Academic Press.

BirdLife International (2004) Threatened birds of the world 2004. CD-ROM. Cambridge, U.K.: BirdLife International.

Blom, P. H. (1987) Capturing and handling raptors. In B. A. G. Pendleton, B. A. Millsap, K. W. Cline and D. M. Bird, eds. Raptor management techniques manual. Washington, D.C: National Wildlife Federation.

Copello, S. and Favero, M. (2001) Foraging ecology of Olrog's Gull Larus atlanticus in Mar Chiquita Lagoon (Buenos Aires, Argentina): are there age-related differences? Bird Conserv. Int. 11: 175-188.

Croxall, J. P. (1998) Research and conservation: a future for albatrosses? Pp. 26-290 in G. Robertson and R. Gales, eds. Albatross biology and conservation. Chipping Norton: Surrey Beatty and Sons.

Delhey, J. K. V., Carrete, M. and Martínez, M. (2001) Diet and feeding behaviour of Olrog's Gull Larus atlanticus in Bahía Blanca, Argentina. Ardea 89: 319-329.

Favero, M., Bachmann, S., Copello, S., Mariano-Jelicich, R., Silva, M. P., Ghys, M., Khatchikian, C. and Mauco, L. (200I) Aves marinas del Sudeste Bonaerense. Pp. $311-318$ in O. Iribarne, ed. Reserva de biósfera Mar Chiquita: características físicas, biológicas y ecológicas. Mar del Plata, Argentina: Editorial Martín.

Favero, M., Khatchikian, C. E., Arias, A., Silva Rodriguez, M. P., Cañete, G. and
Mariano-Jelicich, R. (2003) Estimates of seabird by-catch along the Patagonian Shelf by Argentine longline fishing vessels: 1999-2001. Bird Conserv. Int. 13: 273-281.

Giaccardi, M. and Yorio, P. (2004) Temporal patterns of abundance and waste use by Kelp Gulls, Larus dominicanus, in Patagonia, Argentina. Ornitol. Neotrop. 15: 93-102.

Harrison, P. (1983) Seabirds: an identification guide. Boston, MA: Houghton Mifflin.

Martinez, M. M., Isacch, J. P. and Rojas, M. (2000) Olrog's Gull Larus atlanticus: specialist or generalist? Bird Conserv. Int. 10: 89-92.

Silva, M. P., Favero, M., Berón, M. P., Mariano-Jelicich, R. and Mauco, L. (2005) Ecología y conservación de aves marinas que utilizan el litoral bonaerense como area de invernada. Hornero 20: 111-130.

Spivak, E. and Sánchez, N. (1992) Prey selection by Larus belcheri atlanticus in Mar Chiquita lagoon, Buenos Aires, Argentina: a possible explanation for its discontinuous distribution. Rev. Chil. Hist. Nat. 65: 209-220.

Tasker, M. L., Camphuysen, C. J., Cooper, J., Garthe, S., Montevecchi, W. A. and Blaber, S. J. M. (2000) The impacts of fishing on marine birds. ICES J. Mar. Sci. 57: 531-547.

Yorio, P., Frere, E., Gandini, P. and Conway, W. (1999) Status and conservation of seabirds breeding in Argentina. Bird Conserv. Int. 9: 299-314.

Yorio, P., Bertellotti, M. and García Borboroglu, P. (2005) Estado poblacional y de conservación de gaviotas que se reproducen en el Litoral marítimo Argentino. Hornero 20: 53-74. 
MARÍA PAULA BERÓN*

Universidad Nacional de Mar del Plata, Facultad Ciencias Exactas y Naturales, Departamento Biología, Funes 3250 (B7602AYJ) Mar del Plata, Argentina.

Consejo Nacional de Investigaciones Científicas y Técnicas (CONICET). Av. Rivadavia 1917 (C1033AAJ), Buenos Aires, Argentina

\section{MARCO FAVERO}

Universidad Nacional de Mar del Plata, Facultad Ciencias Exactas y Naturales, Departamento Biología, Funes 3250 (B7602AYJ) Mar del Plata, Argentina.

Consejo Nacional de Investigaciones Científicas y Técnicas (CONICET), Av. Rivadavia 1917 (C1033 AAJ) Buenos Aires, Argentina

\section{AGUSTINA GÓMEZ LAICH}

Universidad Nacional de Mar del Plata, Facultad Ciencias Exactas y Naturales, Departamento Biología, Funes 3250 (B7602AYJ) Mar del Plata, Argentina.

*Author for correspondence; e-mail: mpberon@mdp.edu.ar

Received 13 September 2006; revision accepted 20 February 2007 